\title{
The Thought of Developing Halal Maritime Tourism Destination Towards Indonesia's Vision as a World Maritime Axis
}

\author{
Anita Afriani Sinulingga*, Silsila Asri, Sofia Trisni \\ Jurusan Ilmu Hubungan Internasional, Fakultas Ilmu Sosial dan Ilmu Politik, \\ Universitas Andalas, Kampus Unand Limau Manis Padang-25163 \\ Telp. (0751) 71266, Fax. (0751) 71266, \\ E-mail: anitaafriani@soc.unand.ac.id
}

\begin{abstract}
Indonesia's Vision into the World Maritime Axis is an opportunity for Indonesia to internationalize the sub-national region. The geographical conditions and natural resources are the main capital to achieve that vision. Marine tourism particularly coastal tourism is one of the priority of Indonesia's strategic plan towards the vision of 2030. In addition, trend of halal tourism is a great opportunity for Indonesia to develop marine halal tourism destination. In 2016, Indonesia won World Halal Tourism Award.Consequently, Indonesia established West Sumatra, Aceh and West Nusa Tenggara as a halal tourism destination. Sub-national governments have a significant role to apply the vision mentioned above. This paper focuses on the role of local government as a key actor in planning and implementing domestic economic development policies that are heavily influenced by regional and global political economic development trends. The role of sub-national actors in this case is explained by the exploration of the concept of halal tourism, globalization strategy and Entrepreneurial City. Halal tourism is a tourism industry that meets the concept of halal based on Islamic law. The idea of halal marine tourism in West Sumatra is an effort of local government to improve the economic competitiveness within the Halal tourism sector. The idea is in line with a globalization strategy that promotes the reconsolidation of industrial growth and infrastructure investment in regional economies and strategic urban areas. Therefore, the government needs to arrange a series of strategies as Entrepreneurial City that can accommodate the idea of maritime tourism in the field of policy, governance and empowerment of local communities.
\end{abstract}

Keyword: Indonesia, Marine Tourism, Halal Tourism, Maritime Shaft of the World

\begin{abstract}
ABSTRAK
Visi Indonesia menjadi Poros Maritim Dunia merupakan peluang bagi Indonesia untuk menginternasionalisasi kawasan sub-nasional. Kondisi geografis dan sumber daya alam yang dimilikinya merupakan modal utama untuk mencapai visi tersebut. Wisata bahari khususnya wisata pantai dan pesisir merupakan salah satu prioritas program kerja Indonesia menuju visi 2030. Di sisi lain, perkembangan tren pariwisata halal di dunia merupakan peluang yang besar bagi Indonesia untuk mengembangkan wilayah baharinya sebagai destinasi wisata halal bahari. Pada tahun 2016, Indonesia memperoleh penghargaan sebagai pemenang dalam World Halal Tourism Award 2016. Sejalan dengan penghargaan tersebut, Indonesia menetapkan Sumatera Barat, Aceh dan Nusa Tenggara Barat sebagai destinasi wisata halal di Indonesia. Pemerintah sub-nasional memiliki peran yang signifikan untuk mewujudkan visi tersebut di atas. Tulisan ini memusatkan perhatian pada peran pemerintah daerah sebagai aktor utama dalam merencanakan dan mengimplementasikan kebijakan pembangunan ekonomi domestik yang mendapat pengaruh sangat besar dari kecenderungan perkembangan ekonomi politik kawasan dan global. Peran aktor sub-nasional dalam hal ini dijelaskan dengan eksplorasi konsep pariwisata halal, strategi glocalization dan Entrepreneurial City. Pariwisata Halal merupakanindustri pariwisata yang memenuhi konsep halal berdasarkan ajaran hukum Islam. Ide wisata halal bahari di Sumatera Barat merupakan sebuah upaya pemerintah daerah untuk meningkatkan daya saing ekonomi
\end{abstract}


suatu wilayah dalam sektor pariwisata Halal. Ide tersebut sejalan dengan dengan strategi glocalizationyang mempromosikan rekonsentrasi pertumbuhan industri dan investasi infrastruktur dalam ekonomi regional dan wilayah perkotaan yang strategis. Oleh karena itu, pemerintah perlu menyusun serangkaian strategi sebagai Entrepreneurial Cityyang mampu mengakomodir ide wisata halal bahari dalam bidang kebijakan, tata kelola pemerintahan dan pemberdayaan masyarakat daerah.

Kata Kunci: Indonesia, Wisata Bahari, Pariwisata Halal, Poros Maritim Dunia

\section{Indonesia dan Visi Poros Maritim Dunia 2030}

Poros Maritim Dunia merupakan visi global dari pemerintahan Joko Widodo yang ditargetkan tercapai pada tahun 2030. Untuk mewujudkan Visi 2030, telah disusun Kebijakan Maritim Indonesia yang disusun dengan mengacu pada Visi Pembangunan Indonesia yang tertuang dalam Undang-undang No.17 tahun 2007 tentang Rencana Pembangunan Jangka Panjang Nasional 2005-2025 dan Undang-undang No.32 tahun 2014 tentang Kelautan. Pada tahun 2030, diharapkan Indonesia mampu menjadi role model bagi dunia internasional dalam bidang kelautan termasuk cara menata pembangunan kelautan/ ocean governance (Kebijakan Kelautan Indonesia, Kemenko Bidang Maritim RI, 2017). Secara nominal, pemerintah menargetkan perolehan pendapatan per tahun dari sektor maritim sebesar Rp.5000 triliun pada tahun 2030 .

Untuk mencapai visi tersebut, Indonesia memiliki potensi yang besar sebagai modal utama. Indonesia merupakan negara kepulauan terbesar di dunia dengan kandungan sumber daya alam yang melimpah dan berada di posisi strategis di antara dua benua dan dua samudera. Selain kondisi geografis, Indonesia juga menyimpan potensi kemaritiman berupa garis pantai yang membentang sepanjang $99.149 \mathrm{~km}$, luas daratan sebesar 1.913.578,68 km2, gugusan pulau sebanyak 14.572 dan luas perairan sebesar 6.292.156,82 km2 (Data Badan Informasi Geospasial, 2016). Hingga tahun 2030, usia produktif penduduknya mencapai $70 \%$ sebagai bonus demografis Indonesia.

Salah satu prinsip dasar dalam kebijakan kelautan tersebut yaitu ekonomi biru (blue economy). Pasal 14 UU No.32 tahun 2014 tentang Kelautan mengatur bahwa pemerintah pusat dan pemerintah daerah sesuai dengan kewenangannya melakukan pengelolaan kelautan untuk kemakmuran rakyat melalui pemanfaatan dan pengusahaan sumber daya kelautan dengan prinsip ekonomi biru. Dapat dikatakan bahwa Poros Maritim Dunia merupakan sebuah peluang bagi Indonesia untuk menginternasionalisasi kawasankawasan sub-nasionalnya, baik kota maupun provinsi. Visi Indonesia sebagai Poros Maritim Dunia akan tercapai jika wilayah-wilayah sub nasional baik provinsi, kabupaten/ kota, kecamatan, keluarahan hingga desa mempunyai visi yang menunjang visi 
pemerintah pusat yaitu menjadi Poros Maritim Indonesia. Visi tersebut dapat diterapkan di daerah dengan melakukan penyesuaian terhadap potensi dan kondisi daerah yang bersangkutan, sehingga sehingga setiap daerah memiliki kekhasan dan konsentrasi yang berbeda.

\section{Pariwisata Halal dan Ide Wisata Halal Bahari}

Tulisan ini memusatkan perhatian pada peran pemerintah daerah sebagai aktor utama dalam merencanakan dan mengimplementasikan kebijakan pembangunan ekonomi domestik yang mendapat pengaruh sangat besar dari kecenderungan perkembangan ekonomi politik kawasan dan global. Pemerintah daerah bergerak dalam koridor peraturan otonomi daerah yang telah diaplikasikan di Indonesia sejak tahun 2001. Dalam hal ini, terjadi pergeseran tata kelola pemerintahan dalam mengatur kebijakan-kebijakan ekonomi, dimana pemerintah lokal (otoritas lokal) mulai mengambil peran yang semakin signifikan. David Harvey (Harvey, 1989 dalam Chien dan Ho, 2011: hal 315) mengemukakan bahwa dalam konteks globalisasi, kota atau wilayah tertentu dalam sebuah negara tanpa bisa dicegah telah menjadi bagian integral dari ekonomi dunia. Kondisi ini menstimulasi pemerintah lokal untuk terlibat aktif dalam mengembangkan daya saing ekonomi wilayahnya secara global bahkan terkadang mereka mengambil langkah-langkah kebijakan yang bersifat inovatif untuk beradaptasi dengan proses globalisasi.

Pariwisata halal dunia merupakan salah satu kecenderungan perkembangan ekonomi global yang beorientasi pada industri halal sebagai gaya hidup global. Pariwisata halal muncul dan berkembang sebagai hasil dari inovasi dan upgrading bidang pariwisata untuk memenuhi kebutuhan pasar yakni wisatawan muslim (consumer driven). Perkembangan pariwisata halal tergolong cukup massif secara global seiring dengan semakin besarnya jumlah populasi muslim dunia. Terminologi halal yang dilekatkan pada pariwisata memberikan pengertian bahwa industri pariwisata mulai banyak dikembangkan untuk memenuhi kebutuhan umat muslim dalam melakukan wisata, baik di negara muslim dan berpenduduk mayoritas muslim maupun di negara non muslim dan yang penduduknya mayoritasnya non muslim. Kebutuhan umat muslim dalam berwisata ini berkaitan dengan hukum syariah (ajaran Islam) yang berdasarkan pada Quran dan Hadis.

Menurut Mohammed Battour dan Mohd Nazari Ismail (2015) mendefenisikan Pariwisata halal sebagai berikut; “...any tourism object or action which is permissible according to Islamic teachings to use or engage by Muslims in tourism industry". Dalam 
konteks ini industri pariwisata harus memenuhi konsep halal berdasakan ajaran hukum Islam. Definisi halal merujuk pada pendapat ulama besar Islam adalah segala sesuatu yang diperolehkan, segala sesuatu yang tidak ada larangan dan dilakukan sesuai dengan petunjuk yang diberikan Allah. Konsep pariwisata halal meliputi beberapa aspek seperti makanan dan minuman halal, lokasi tujuan wisata yang di samping memberikan kesenangan juga memberikan kemudahan dalam melaksanakan ibadah dan ada pemisahan lokasi antara laki-laki dan perempuan serta pakaian dan semua produk barang dan jasa pendukung lainnya yang halal menurut hukum Islam. Konsep tersebut dapat diterapkan di lokasi wisata yang tidak hanya berpenduduk mayoritas Islam tetapi juga negara-negara non muslim.

Defenisi lain yang senada dikemukakan oleh Hussein Elasrag (2016) tentang pariwisata halal adalah

"It refers to tourism products that provide hospitality services in accordance with Islamic beliefs and practices. This involves serving halal food, having separate swimming pools, spa and leisure activities for men and women, alcohol free dining areas, prayer facilities, and even women-only beach areas with Islamic swimming etiquette."

Defenisi di atas memberikan contoh pariwisata halal yang sangat spesifik. Prakteknya di beberapa tempat seperti Thailand, Taiwan dan Hongkong juga memberikan best practice seperti adanya kopian mushaf Quran di Mushola. Negara-negara non muslim ini mampu memberikan kenyamanan dan berupaya memenuhi kebutuhan wisatawan muslim selama berwisata di lokasi-lokasi wisata mereka. Tentunya di wilayah atau kota yang berpenduduk mayoritas muslim produk dan pelayanan seperti di atas bukan suatu kelebihan yang perlu ditonjolkan. Oleh karena itu perlu dilakukan inovasi yang lebih menarik lagi dalam mengembangkan pariwisata halal.

Miller dan Keohane (1996) menjelaskan dinamika ekonomi yang terjadi di lingkungan domestik berhubungan erat dengan perkembangan liberalisasi dalam rezim ekonomi dan perdagangan internasional. Setiap negara akan merespon pengaruh dari setiap rezim internasional ataupun proses internasionalisasi yang terjadi dengan cara yang berbeda sesuai dengan kapabiltas dan kepentingan nasionalnya. Keterbukaan terhadap aktivitas ekonomi internasional akan membentuk dan mempertajam kepentingan serta pilihan-pilihan kebijakan aktor-aktor ekonomi domestik dan pemerintah setempat sebagai regulator dan pihak yang memiliki otoritas. Jeffery Frieden dan Ronald Rogowski mengemukakan bahwa internasionalisasi berpengaruh terhadap peluang dan hambatan 
yang dihadapi oleh aktor-aktor sosial ekonomi dan begitu juga pilihan-pilihan kebijakan mereka. Pilihan kebijakan rasional dalam kondisi tersebut adalah pilihan kebijakan yang berorientasi pada pencapaian tujuan-tujuan fundamental. Hal ini selanjutnya akan berimplikasi pada pembentukan kebijakan ekonomi domestik dan institusi-institusi politik dan ekonomi domestik (Keohane: hal 8). Pariwisata halal menjadi salah satu sektor ekonomi yang memiliki daya saing yang tinggi saat ini dalam perkembangan ekonomi global. Daya saing ekonomi suatu wilayah diperoleh dari kemampuan untuk memobilisasi keunggulan komparatif dan keunggulan kompetitif yang saling mempengaruhi menjadi sektor-sektor yang memiliki nilai tambah dalam rantai nilai ekonomi global.

Pada 07 December 2016 di Abu Dhabi, Uni Emirat Arab, Indonesia mendapatkan penghargaan pada 12 kategori dari 16 kategori dalam Wold Halal Tourism Award (WHTA). WHTA merupakan penghargaan yang diberikan kepada destinasi - destinasi wisata yang mengusung konsep Halal. Destinasi halal yang dimaksud adalah pariwisata ramah wisatawan muslim (moslem friendly tourism). Konkritnya, destinasi wisata tersebut dilengkapi dengan fasilitas halal misalnya mudah ditemukannya masjid, tempat wudhu, hotel memiliki petunjuk arah kiblat, jam shalat, kitab suci, dan lain sebagainya. Sebelumnya pada tahun 2015 dan 2016, Malaysia dan Turki merupakan negara-negara yang memenangkan perhargaan tersebut. Mengikuti ajang kompetisi tersebut dirasa penting bagi pemerintah Indonesia sebagai sebuah cara mempromosikan pariwisata halal pada khususnya dan pariwisata Indonesia pada umumnya. Melalui sektor pariwisata halal tersebut diharapkan terjadi peningkatan pendapatan produk domestik bruto (PDB), devisa negara, dan jumlah lapangan pekerjaan. Jenis-jenis penghargaan tersebut dapat dilihat pada tabel 1 .

Tabel 1. Kategori Penghargaan yang Dimenangkan oleh Indonesia dalam World Halal Tourism Award 2016

\begin{tabular}{|l|l|l|}
\hline No & \multicolumn{1}{|c|}{ Kategori Penghargaan } & \multicolumn{1}{c|}{ Brand/ Lokasi di Indonesia } \\
\hline 1 & $\begin{array}{l}\text { World's Best Airline for Halal } \\
\text { Travellers }\end{array}$ & Garuda Indonesia \\
\hline 2 & $\begin{array}{l}\text { World's Best Airport for Halal } \\
\text { Travellers }\end{array}$ & $\begin{array}{l}\text { Sultan Iskandar Muda International } \\
\text { Airport, Aceh }\end{array}$ \\
\hline 3 & World's Best Family Friendly Hotel & The Rhadana Hotel Bali \\
\hline 4 & $\begin{array}{l}\text { World's Most Luxurious Family } \\
\text { Friendly Hotel }\end{array}$ & Trans Luxury Hotel Bandung \\
\hline 5 & World's Best Halal Beach Resort & $\begin{array}{l}\text { Novotel Lombok Resort \& Villas, } \\
\text { NTB. }\end{array}$ \\
\hline 6 & World's Best Halal Tour Operator & Ero Tour, West Sumatera \\
\hline 7 & World's Best Pariwisata halal & www.wonderfullomboksumbawa.com \\
\hline
\end{tabular}




\begin{tabular}{|c|c|c|}
\hline & Website & \\
\hline 8 & $\begin{array}{l}\text { World's Best Halal Honeymoon } \\
\text { Destination }\end{array}$ & $\begin{array}{l}\text { Sembalun Village Region, Lombok, } \\
\text { Nusa Tenggara Barat }\end{array}$ \\
\hline 9 & World's Best Hajj \& Umrah Operator & ESQ Tours \& Travel, Jakarta \\
\hline 10 & World's Best Halal Destination & West Sumatera \\
\hline 11 & $\begin{array}{l}\text { World's Best Halal Culinary } \\
\text { Destination }\end{array}$ & West Sumatera \\
\hline 12 & $\begin{array}{l}\text { World's Best Halal Cultural } \\
\text { Destination }\end{array}$ & Aceh \\
\hline
\end{tabular}

Sumber: nationalgeographic.co.id

Saat ini pemerintah Indonesia menetapkan wilayah Sumatera Barat, Aceh dan Sumatera Barat sebagai destinasi wisata halal di Indonesia. Sumatera Barat sendiri memiliki wilayah pesisir di tujuh kabupaten dan kota yaitu Kepulauan Mentawai, Pasaman Barat, Agam, Padang Pariaman, Kota Pariaman, Kota Padang dan Pesisir Selatan dengan luas laut kurang lebih 37.363,75 km2, panjang garis pantai 1973, $24 \mathrm{~km}$, jumlah pulau 185 buah. Dalam RPJM Sumatera Barat, dijelaskan bahwa pengembangan kawasan pantai dan pulau-pulau yang ada sebagai objek pariwisata dengan program pengembangan kawasan wisata pantai merupakan salah satu prioritas pemerintah (www.sumbarprov.go.id). Saat ini, Sumatera Barat dikenal dengan pulau Mandeh yang keindahannya disebut setara dengan Raja Ampat di Papua. Hal ini merupakan modal utama bagi Sumatera Barat menjadi Poros Maritim Indonesia.

Kondisi alamnya mendukung Sumatera Barat untuk memiliki keunggulan komparatif dalam sektor pariwisata, sehingga konsep pariwisata pun mulai diarahkan kepada konsep pariwisata halal dunia. Penghargaan yang diterima oleh Indonesia dalam World Halal Tourism Award 2016 memperlihatkan Sumatera Barat, dengan kemenangan pada tiga kategori, merupakan destinasi wisata di Indonesia dengan fokus pariwisata halal yang diminati oleh dunia internasional. Meskipun Sumatera Barat telah memperoleh penghargaan secara global untuk pariwisata halal dunia, Sumatera Barat masih belum memaksimalkan potensi tersebut untuk peningkatan kesejahteraan secara keseluruhan. Oleh karena itu pemerintah lokal Sumatera Barat perlu membuat strategi yang tepat sasaran dalam mengembangkan potensi pariwisata halal dunia ini khususnya dalam pengembangan wisata halal bahari. Target pasar Sumatera Barat dalam pengembangan pariwisata halal dunia ini tidak lagi wisatawan domestik melainkan wisatawan internasional khususnya wisatawan muslim manca negara.

Internasionaliasi ekonomi menghendaki perubahan institusional dan kebijakan yang sinergis. Perubahan-perubahan tersebut bisa meliputi liberalisasi perdagangan dan 
kebijakan investasi, deregulasi pasar domestik, peralihan kebijakan fiskal dan moneter, perubahan institusi-institusi yang didesain untuk mengimplementasikan perubahanperubahan kebijakan. Institusi politik mencerminkan pilihan kebijakan aktor-aktor domestik karena mereka bertujuan menciptakan jaminan untuk pencapaian kepentingan tertentu (Keohane: hal 9-14). Dengan demikian, pemerintahan suatu negara terutama daerah yang bersinggungan langsung dengan dinamika perdagangan internasional dan internasionaliasasi ekonomi tersebut harus membuat pilihan kebijakan yang rasional dan pragmatis agar dapat mengambil keuntungan dari peluang yang tercipta dalam proses internasionaliasi ekonomi tersebut.

Strategi yang proaktif merupakan tindakan-tindakan strategik yang mendukung terhadap perkembangan global. Dalam hal ini dapat diartikan bahwa tindakan-tindakan penyesuaian yang dilakukan oleh negara telah diproses melalui serangkaian pertimbanganpertimbangan yang rasional. Sehingga negara dapat mengarahkan haluannya mengikuti arus perkembangan globalisasi. Pilihan kebijakan ini terkait dengan kemampuan modal dan ilmu pengetahuan serta teknologi negara tersebut. Negara-negara sedang berkembang seperti Indonesia dihadapkan pada persoalan modal dan teknologi. Namun kondisi ini bukanlah merupakan suatu takdir yang tidak dapat diubah. Pemerintah suatu negara memiliki kedaulatan untuk mengarahkan orientasi kebijakan pembangunan ekonominya. Negara berperan strategis dalam mengarahkan perubahan substansial suatu wilayah untuk memaksimalkan pendapatan demi kesejahteraan masyarakatnya yang sering disebut sebagai structural change (Chang, 2003: hal. 83). Pengembangan suatu wilayah pesisir pantai menjadi kawasan pariwisata halal membutuhkan suatu perubahan struktural yang sangat signifikan, baik dari segi infrastruktur maupun dari segi regulasi.

\section{Peran Pemerintah Daerah dalam Ide Pengembangan Wisata Halal Bahari}

Berbagai pendekatan dapat digunakan untuk mengembangkan kawasan pesisir pantai dengan konsep wisata halal bahari. Penekanannya adalah peran signifikan dari pemerintah lokal sebagai otoritas yang berwenang dalam konteks otonomi daerah Negara Kesatuan Republik Indonesia. Tulisan ini mencoba untuk mengetengahkan pendekatan glocalization dan urban entrepreneurialism.

Penggunaan konsep the entrepreneurial city bersama dengan konsep entrepreneurial governance dan urban entrepreneurialism merupakan suatu cara bagi para teoritisi perkotaan untuk menjawab perubahan-perubahan akibat proses internasionalisasi dan proses-proses berbeda yang harus dihadapi oleh suatu pemerintahan lokal sehubungan 
dengan globalisasi. Untuk mengelola politik, ekonomi dan sosial serta dalam menghadapi tekanan krisis fiskal, tingkat pengangguran yang tinggi, kota-kota di dunia seringkali merensponnya dengan memperkenalkan perubahan kebijakan baru dan juga dengan memperkenalkan elemen-elemen organisasional baru dalam pemerintahan lokal.

Entrepreneurial city atau urban entrepreneurialism muncul dalam kajian para teoritisi perkotaan tahun 1970-an di Eropa, paska kegagalan welfare state keynessian. Neil Brenner memperkenalkan konsep glocalization yang kemudian menghadirkan konsep urban entrepreneurialism sebagai sebuah proses transformasi tata kelola wilayah strategik ekonomi dalam suatu negara dalam tulisannya yang berjudul 'Glocalization' as a State Spatial Strategy: Urban Entrepreneurialism and the New Politics of Uneven Development in Western Europe” (Brenner,2004). Konsep glocalizing states berupaya untuk membedakan tata ruang politik-ekonomi nasional melalui rekonsentrasi kapasitas ekonomi kedalam pusat-pusat pertumbuhan ekonomi regional dan wilayah perkotaan yang strategis. Istilah glocal- yang merupakan perpaduan antara global dan lokal- merupakan label yang tepat untuk kecenderungan sejauh mana strategi-strategi politik memposisikan tata ruang subnasional tertentu (lokal, kota, region, daerah industri) dalam ruang lingkup sirkuit aktivitas ekonomi supranasional. Strategi glocalization mempromosikan rekonsentrasi pertumbuhan industri dan investasi infrastruktur dalam ekonomi regional dan wilayah perkotaan yang strategis. Pendekatan entrepreneurial harus dipandang sebagai salah satu komponen kunci dalam strategi glocalization. Oleh karena itu glocalization merupakan suatu proses rekalibrasi kekuasaan geografi nasional negara dalam cara untuk mencapai skala regional dan lokal sebagai wilayah strategik untuk pengembangan sektor-sektor ekonomi tertentu.

David Harvey adalah teoritisi yang pertama menggunakan kerangka konseptual ini. Mengikuti kerangka pemikiran Harvey (dalam Dannestam, 2004), pemetaan entrepreneurial city telah berkembang menjadi perspektif teoritis dalam 3 elemen utama. Pertama, peran pemerintah lokal dalam memajukan pembangunan ekonomi yang mengacu pada konten atau kebijakan politik lokal. Kedua, adanya penekanan terhadap keterlibatan aktor swasta dan cara-cara baru dalam mengoraganisasikan administrasi publik. Konsep ini diturunkan menjadi organisasi politik lokal atau entrepreneurial governance. Ketiga, globalisasi ekonomi seringkali digunakan untuk menjelaskan kemunculan the entrepreneurial city.

Hubbard dan Hall (dalam Dannestam: hal 8), mengemukakan bahwa pemerintah lokal tidak hanya sebagai penyedia pelayanan untuk kesejahteraan namun juga untuk 
mempromosikan dan mendorong pembangunan ekonomi dan pertumbuhan ekonomi lokal. Manifestasi suatu entrepreneurial policy dalam mengembangkan pariwisata halal bahari dapat ditunjukkan melalui strategi yang beranekaragam misalnya memberikan insentif kepada pelaku usaha yang berinovasi melahirkan produk dan layanan pariwisata halal. Strategi tersebut juga dapat meliputi cara-cara untuk mempromosikan suatu wilayah pesisir sebagai wisata bahari yang moslem friendly. Akhirnya entrepreneurial policy dapat meliputi proyek-proyek spektakuler pariwisata halal yang bersinergi dengan proyek pembangunan daerah secara keseluruhan.

Tema umum yang juga sangat penting dalam entrepreneurial policy ini adalah ilmu pengetahuan dan teknologi tinggi dalam mengembangkan bisnis, berfungsi untuk membuat suatu maneuver ekonomi yang inovatif. Adminitrasi kota secara aktif berupaya untuk mempromosikan terbentuknya cabang-cabang baru ekonomi misalnya melalui penciptaan unit-unit bisnis pariwisata halal. Selanjutnya adalah penciptaan iklim bisnis yang bersahabat merupakan isu yang menjadi prioritas utama saat ini. Administrasi publik lokal seharusnya memiliki attitude yang mendorong terciptanya iklim bisnis yang kondusif dan dimanifestasikan secara aktif dalam pembangunan ekonomi lokal. Terciptanya mutual understanding diantara para politisi terkemuka dan para pegawai negeri sipil untuk menarik kelompok kelompok bisnis kewilayah mereka. Lingkungan tempat tinggal yang nyaman, kualitas perumahan dan pelayanan yang bagus akan menarik orang orang untuk bertempat tinggal dilingkungan tersebut dan selanjutnya akan menarik investasi, pembukaan bisnis baru dan akhirnya membuka kesempatan kerja.

Elemen kedua dalam membangun entrepreneurial city adalah perubahan dalam organisasi politik lokal. Para penstudi yang berkecimpung dalam kajian ini menyebutnya peralihan dari "managerialism" menuju "entrepreneurial governance" (Harvey, 1989; Short \& Kim, 1999; Ruppert, 2000 dalam Dannestam: hal 11). Karakter politik lokal berubah dari lokal welfare state dimana politik dipraktekkan dalam garis lingkungan pengaruh publik menjadi suatu arena yang lebih terfragmentasi melalui kemunculan aktoraktor baru. Para teoritisi ini menyebutnya dengan suatu penggantian (displacement) dari aktivitas sektor publik menjadi aktivitas sektor swasta, atau mengakibatkan batasan yang kabur antara keduanya. Penekanan yang lebih umum atau yang kurang drastis adalah model tata kelola pemerintahan public - private partnerships (dalam Dannestam: hal 13)

Mengembangkan pariwisata halal bahari di Sumatera Barat merupakan upaya rekonsentrasi aktivitas pertumbuhan ekonomi dengan memanfaatkan keunggulan komparatif lokal (daerah) yakni potensi pariwisata maritim (bahari) dan budaya 
Minangkabau yang dekat dengan Islam. Sebagai elemen ketiga dari pemikiran Hubbard dan Hall, strategi glocalization menekankan pada pentingnya peran administrasi publik lokal dan otoritas lokal dalam mengarahkan pertumbuhan ekonomi melalui implementasi kebijakan entrepreneurial city yakni memberdayakan dan mengaktifkan kewirausahaan lokal untuk membangun unit-unit ekonomi yang berkontribusi pada peningkatan kesejahteraan. Dalam pengembangan wisata halal bahari, pemerintah lokal perlu bertransformasi dari sebagai pengelola (fasilitator dan regulator) menjadi aktor yang juga bertindak sebagai pelaku bisnis dan mendorong tumbuh dan berkembangnya unit-unit ekonomi pariwisata halal tersebut. Dalam proses ini pemerintah perlu membangun lingkungan bisnis yang kondusif dan sinergi antara sektor publik dan sektor swasta.

\section{Kesimpulan}

Menjadi Poros Maritim Dunia pada tahun 2030 dideklarasikan sebagai visi global pemerintahan Joko Widodo. Selain sebagai sebuah identitas bangsa, sektor maritim diharapkan menjadi salah satu sumber utama devisa negara. Potensi kekayaan alam dan letak geografis yang strategis merupakan modal utama bagi Indonesia untuk mewujudkan visi tersebut. Sementara itu di dunia internasional, pariwisata halal tengah menjadi sebuah gaya hidup global. Pariwisata halal dunia merupakan salah satu kecenderungan perkembangan ekonomi global yang beorientasi pada industri halal. Wisatawan muslim merupakan sebuah pasar yang sangat besar bagi pariwisata halal. Saat ini, pariwisata halal bukan hanya dikembangkan oleh negara-negara dengan penduduk mayoritas muslim, tapi juga negara-negara non muslim seperti Thailand, Taiwan dan Hongkong. Negara-negara non muslim tersebut mampu memberikan kenyamanan dan berupaya memenuhi kebutuhan wisatawan muslim selama berwisata di lokasi-lokasi wisata mereka.

Indonesia merupakan negara pemenang kompetisi World Halal Tourism Award 2016. Sejalan dengan penghargaan tersebut, pemerintah Indonesia menetapkan Sumatera Barat sebagai salah satu destinasi wisata halal di Indonesia. Berangkat dari potensi pantai dan pesisir yang dimilikinya, ide wisata halal bahari di Sumatera Barat merupakan sebuah upaya pemerintah daerah untuk meningkatkan daya saing ekonomi suatu wilayah dalam sektor pariwisata halal. Untuk mewujudkan ide tersebut, pemerintah daerah perlu melakukan serangkaian strategi yang mampu mengakomodir kebutuhan dalam destinasi wisata halal bahari. 


\section{Daftar Pustaka}

Battour, M., \& Ismail, M.N., (2015) Halal Tourism: Concepts, Practises, Challenges and Future, Tourism Management Perspectives.

Brenner, Neil., "Glocalization” as A State Spatial Strategy: Urban Entrepreneurialism and The New Politics of Uneven Development in Western Europe dalam Jamie Peck dan Henry Wai-chun Yeung (eds), (2003), Remaking the Global Economy: EconomicGeographical Perspective, SAGE Publication

Chang, Ha-Joon., (2003), “Globalization, Economic Development and Structural Change”, Zed Books Ltd, London

Chien, Shiuh-Shen dan Bing Ho., (2011), Globalization and Local Government Learning Process in Post-Mao China: a Transnational Perspective, Jurnal Compilation Global Network 11, Blackwell Publishing Ltd and Global Network Partnership, Taiwan.

Data Badan Informasi Geospasial, (2016)

Elasrag, Hussein., (2016), Halal Industry: Key Challenges and Opportunities, MPRA Paper No. 69631

Harvey, David dalam Tove Dannestam (2004), The Theories and Politics of Entrepreneurial Cities-a Theoretical Summing up and the Next Step Forward, Lund University

Kebijakan Kelautan Indonesia, Kemenko Bidang Maritim RI, (2017)

Miller, Hellen V. dan Robert O. Keohane., (1996) Internationalization and Domestic Politics: An Introduction, Cambridge University Press UK nationalgeographic.co.id 